\title{
Paz no es ausencia de conflicto: Es desarrollo y seguridad
}

\section{Silvio Lerer' conversa con Josep Redorta}

Podría resultar paradójico que dos expertos en conflictos y en su resolución no pudieran ponerse de acuerdo y no encontraran los modos de solucionar sus diferencias. Pero las discrepancias entre las personas son parte ineludible de la convivencia humana y muchas de ellas no tienen conclusión, pero lo que sí es un desatino es que esos especialistas no puedan tener un diálogo integral.

Pienso en ello mientras me encamino hacia el sitio de encuentro donde me espera el maestro Josep Redorta para este reportaje. Porque conozco a mi entrevistado, estoy seguro de que el diálogo será, además, instructivo y pedagógico; Redorta también enseña al dialogar.

Me aguarda en la confitería del hotel donde se hospeda en su primera visita a Cali. El sitio de la reunión es un lugar agradable pero impersonal y frío como el de cualquier hotel de categoría. Nada se compara con el lugar emblemático en el que nos conocimos en la hermosa Barcelona, su ciudad natal: nada más y nada menos que el palacio de La Pedrera, famoso edificio surgido de la imaginación prodigiosa de Gaudí.

A bordo del ascensor vienen a mi memoria muchos catalanes famosos y en ella resuenan nombres como Luis Buñuel, Pablo Casals, Salvador Dalí, Juan Goytisolo, Montserrat Caballé, Fernán Adriá, Ana María Matute, Josep Pla, Carmen Laforet, Juan Marsé, Santiago Ramón y Cajal, Margarita Xirgu, Alberto Closas y Joan Manuel Serrat. Músicos, artistas, intelectuales, escritores, poetas, actores, científicos y hasta el mejor chef del mundo. Y uno se pregunta-como también muchos lo hacen respecto del pueblo judío- qué es lo que hace que un linaje como el catalán haya hecho semejante contribución a la cultura universal.

Este reportaje no pretende contestar semejante pregunta, pero sí servir como acercamiento a este referente de la mediación y la gestión de conflictos españoles y a sus ideas y principios, y está basado en aquella frase que un día creí inventar: "Un hombre es como es, tanto por sus orígenes, su marca en el orillo, como por lo que piensa, por sus ideas". Genes y pensamiento; destino y albedrío.

Me espera mientras escribe en un cuaderno. Levanta la mirada, se incorpora y sonríe. Tan sabio como amable, me invita a acompañarlo en su mesa y llama al camarero para pedir café. Intercambiadas las frases sociales y protocolares y bebido el primer sorbo, le agradezco el tiempo que nos ha dedicar y prácticamente sin dar tiempo tregua comienzo la entrevista.

Silvio Lerer (S.L.): Me gustaría que nos cuentes algo de ti. ¿Quién eres, Josep? ¿Cuáles son tus origenes? ¿Qué te ha ocurrido en la vida para que un día hayas decidido convertirte en un experto en conflictos y en su gestión?

Josep Redorta (J.R.): La pregunta de quién es cada cual tiene mucha enjundia. La identidad es algo totalmente relevante. Provengo de clase humilde y toda mi carrera-sobre todo al principio-la hice sacándome horas de sueño después de trabajar.

Es buena la pregunta respecto a qué me motivó para entrar en el campo de la gestión de conflictos. He estado en ella siempre -incluso hoy estoy en formación permanente- $y$ hace algo más de veinte años luego de ejercer como abogado litigante comprendí que había vida más allá del derecho. Me lancé a formarme en el área de la psicología social en el cual he tenido grandes satisfacciones. Un congreso europeo de psicología jurídica me abrió los nuevos paradigmas en los que estoy.

(S.L.): Tu educación académica o por lo menos parte de ella, la de tu primera juventud, se desarrolló bajo el franquismo. Franco muere en noviembre de 1975. ¿Cómo influyó esa educación tan férrea y severa en tus ideas y principios?

(J.R.): Esa educación era tan inflexible que teníamos un guardia civil para enseñarnos a hacer instrucción en el patio de la escuela formando filas. Fuimos educados en la

1. Silvio Lerer es un abogado egresado con diploma de honor de la Facultad de Derecho de la Universidad Nacional de Buenos Aires. Obtuvo su Maestría en Derecho Comparado en la Southern Methodist University de Dallas. Además es docente universitario especialista en métodos alternativos, investigador y pionero de la mediación en Latinoamérica. Twitter: @silvioler 
obediencia y no en la reflexión. Tuve la suerte de que un padre escolapio se fijara en mí y me ayudara de los trece a los dieciséis años de edad. Nunca le agradeceré lo bastante.

Como decía, no se nos enseñó a pensar, pero sí a ser perseverantes y coherentes en la medida de nuestras posibilidades. De todas formas, mi formación más importante estuvo más influida por las lecturas y debates ya de mayor. La llamada transición española -además de otras cosasfue un período que nos obligó a pensar, particularmente a aquellos que estamos orientados a la tarea reflexiva y la acción.

(S.L.): Provienes de una comunidad, Cataluña, que desde siempre ha estado en conflicto con España, en busca más que de la autonomía, de la secesión respecto del reino. ¿Cómo crees que ha influido en tu pensamiento, en tu trabajo y en tu obra ese conflicto, esa confrontación permanente entre los nacionalistas catalanes y aquellos que no buscan alejarse o separarse de España?

(J.R.): No. Eso no ha influido en mi formación pero sí en las ideas que profeso actualmente. Mi formación presente me permite entender -diría que con bastante conocimiento de causa- lo que ocurre y por qué ocurre.

(S.L.): Tú, como yo, vienes de la abogacía. Cuéntanos un poco cómo fue tu experiencia profesional como jurista, cuál era tu relación con los litigios y qué te llevó a la psicología social y a la resolución de conflictos.

(J.R.): El ejercicio de la abogacía te ordena mucho la cabeza. Aprendes a asumir riesgos y a hacer planteamientos estratégicos entre otras muchas cosas. Te provee un background del que se pueden aprovechar otras disciplinas. A veces te vuelve demasiado rígido, pero ese nunca fue $\mathrm{mi}$ caso. Si se estudia negociación es un error fatal ignorar el conflicto subyacente a ella y en ese sentido fue un reto descubrir hasta qué punto tenía razón.

(S.L.): Venimos de sociedades acostumbradas a negar las diferencias y los conflictos y a considerarlos negativos y perjudiciales. Esa negación y esa descalificación de la diferencia que España transmitió a sus otrora colonias, hace que para muchos -entre ellos las clases dirigentes- el conflicto sea algo que hay que eliminar a toda costa. ¿En que se basa toda esa concepción y que consecuencias trae para la convivencia social?

(J.R.): Este es un asunto muy claro para la sociología. El funcionalismo asume el conflicto como algo negativo y peligroso mientras el marxismo lo consideró como positivo por ser el motor del cambio. Como se ve, son dos concepciones demasiado alejadas entre sí para entenderse. Eso ha bloqueado la investigación durante decenios, pero es afortunado que esa idea esté cambiando gracias al nuevo paradigma del cambio social. El conflicto y el consenso son dos caras de la misma moneda.

(S.L.): La España de la Unión Europea, del euro y de la modernidad, sufre una grave crisis económica y financiera desde el 2008 que ciertamente conspira contra su estabilidad politica y social. Ello ha sacado a la luz una serie de conflictos sociales que permanecian ocultos durante las épocas más florecientes. ¿Cuáles crees son los conflictos más importantes que dividen hoy día a España y cuáles sus causas?

(J.R.): Se trata de conflictos estructurales que traté particularmente en mi libro Hacia un mundo deseado que prologó D. Federico Mayor Zaragoza, exdirector general de la Unesco y persona de una visión global íntegra. En España (y otros lugares) ha entrado en crisis de legitimación el sistema político y económico. Las causas son múltiples. Es inconcebible que se arroje a una familia de su casa para que el banco se la quede y luego la venda a fondos especulativos. Hay decenas de miles de casos como esos. La élite del poder ha traspasado demasiado los límites.

(S.L.): En tu obra nos has enseñado a comprender y a manejar mejor nuestros conflictos. Esas acciones podrían implicar que no estés totalmente convencido de que la mayoría de las discrepancias interpersonales y sociales tengan solución. En otras palabras, como no son solucionables al menos hay que comprenderlos y manejarlos, o sea, aprender a convivir con ellos. ¿Podrías confirmar o refutar esa apreciación?

(J.R.): Si se revisan los conceptos históricos del sector como transformación de conflictos o bien resolución de conflictos, es claro que es más omnicomprensivo el concepto de gestión de conflictos que abarca todas las herramientas para alcanzar soluciones aceptables. Yo soy optimista en cuanto a las soluciones en términos generales, pero a veces ocurre que el tiempo y la oportunidad hacen una labor que está infravalorada y poco estudiada.

(S.L.): En tus libros más recientes enfatizas en la necesidad de comprender el patrón que siguen los conflictos para obtener mayor información y predecir así su evolución. ¿Significa ello que privilegias las formas que adopta el conflicto sobre sus causas?

(J.R.): La forma y la causa en la filosofía y el pensamiento griegos han actuado de manera dialéctica. Lo que ocurre es que las causas por sí solas son insuficientes para comprender la naturaleza de algunos conflictos al tiempo que la forma ha sido poco estudiada. Es cierto que esta es mi línea de trabajo y, si se quiere, una de mis contribuciones al campo. La técnica del análisis de conflictos por reconocimiento de patrones que he desarrollado aporta

$112<$ Universidad de San Buenaventura, Cali - Colombia 
más luz que la causalidad. De todas maneras, soy de la opinión de que hay que reforzar las dos visiones.

(S.L.): Existe una enorme variedad de conflictos, lo que ha tentado a los autores a clasificarlos según diversos criterios, entre ellos el la tipología funcional de Moore, que es tu favorito. Sin embargo, te ha parecido más operativo hablar de la morfología. ¿Puedes resumirnos cuál es la idea de la morfología y cuál es su importancia práctica?

(J.R.): Deberíamos darnos cuenta de que la enorme variedad de cosas que existen en el mundo físico derivan de las infinitas combinaciones de la llamada tabla periódica de los elementos que alcanzan un número mayor a cien. También el código genético y sus combinaciones son la base de la variedad ingente de lo vivo. En resumen, de pocos elementos comunes sale la diversidad. Somos capaces de aislar esos pocos elementos comunes (yo los he cifrado en dieciséis conflictos-tipo) y si aislamos lo común de los conflictos (el patrón o patrones que siguen) y aquello en lo que difieren (el perfil de conflicto), podemos efectuar un análisis bastante preciso si se conocen los procesos socio-psicológicos que subyacen a un conflicto concreto. La importancia práctica es enorme porque es la base para generar un software con fundamento en inteligencia arti- ficial capaz de canalizar miles de casos y ofrecer criterios de utilidad práctica comunes.

(S.L.): En tu doctrina es fundamental al análisis del conflicto como paso previo a su resolución. Me gustaría saber qué elementos debería reunir un instrumento de análisis de conflictos.

(J.R.): Una herramienta de este tipo debe ser generalizable (aplicable a todos los conflictos, sea cual sea la escala). Al mismo tiempo, debe ser específica; es decir, capaz de identificar lo común y diverso de cada caso. Debe ser de uso práctico y con idea de orientación. No es posible alcanzar precisión ni creo que esta sea conveniente. Precisamos la brújula y no el GPs. Debería poder estar al alcance de todos y enseñarse en la escuela.

Escuchar a Redorta es una oportunidad que bien vale el sacrificio de no consumir por largo rato algo tan delicioso como el café colombiano. Pero debemos continuar nuestro camino, ese que el poeta dice "se construye al andar". Me voy más rico de lo que llegué, con mucho aprendido y mucho por aprender. 